\title{
New records and range extension of some mosses in tropical areas of Chile
}

\author{
María J. Cano \\ Departamento de Biología Vegetal (Botánica), Universidad de Murcia, Campus de Espinardo, \\ 30100 Murcia, Spain; e-mail: mcano@um.es
}

\begin{abstract}
A total of thirteen mosses are reported as new for Chile: Aloinella andina Delgad., Coscinodontella bryanii R.S. Williams, Didymodon acutus (Brid.) K. Saito, Erythrophyllopsis fuscula (Müll. Hal.) Hilp., Fissidens excurrentinervis R.S. Williams, Grimmia molesta J. Muñoz, Grimmia pseudoanodon Deguchi, Jaffueliobryum williamsii (Deguchi) Delgad., Leptopteriginandrum austroalpinum Müll. Hal., Pseudocrossidium elatum (R.S. Williams) Delgad., Rhexophyllum subnigrum (Mitt.) Hilp., Saitobryum lorentzii (Müll. Hal.) Ochyra, and Syntrichia fragilis (Taylor) Ochyra. In addition, Grimmia plagiopodia Hedw., which was previosly known from Southern Chile, is reported ca. $3500 \mathrm{~km}$ more to the north, near the Bolivian border.
\end{abstract}

\section{Introduction}

Northern Chile from the border with Peru and Bolivia to the Tropic of Capricorn has a strong tropical influence. The cold running Humbold, which provides Antarctic water from the south, and the Peruvian deep trough, which provides cold water from the depths of the Pacific Ocean, are responsible for the presence of one of the aridest deserts in the world (Atacama) as opposed to the tropical forests. In the interior of the country, near the Bolivian border, the territory rises abruptly, coming under the influence of the Bolivian ,altiplano“. This area is included in the so-called Bloque Andino Central, an Andine meseta of ca. $3800 \mathrm{~m}$, where the vegetation is influenced by the summer rain (December to March) and the height above sea level. In these conditions, the vegetation, known in general as „puna“, is formed at lower altitudes by different species of Cactaceae, such as Browningia candelaris Britton \& Rose, some grasses and shrubs such as Baccharis boliviensis (Wedd.) Cabrera, Mentzelia ignea (Phil.) Urb. \& Gilg, Trixis cacalioides D. Don and Viguiera pazensis Rusby. From 3600 m to 4000 m, the vegetation consists mainly of small shrubs represented mainly by Asteraceae, such as Parastrephia quadrangularis (Meyen) Cabrera or Senecio nutans Sch. Bip. and above $4000 \mathrm{~m}$, the 
predominat vegetation is formed by the cushions of Azorella compacta Phil. and Pycnophyllum molle Remy and a tree Polylepis tarapacana Phil. (Grau 1995).

From the bryological point of view, there are few data concerning collections in these areas. Thus, according to He (1998), there was no record from Tarapacá (Región I) and only 8 mosses were reported from Antofagasta (Región II): Bryum orthothecium Cardot \& Broth., Cratoneuron filicinum (Hedw.) Spruce, Crossidium roseae R.S. Williams, Juratzkaea seminervis (Kunze ex Schwägr.) Lorentz, Leptobryum stellatum (Herzog) Broth., Pseudocrossidium replicatum (Taylor) R.H. Zander, Pseudoleskea chilensis (Lorentz) Ochyra and Syntrichia scabrinervis (Müll.Hal.) R.H. Zander.

The mosses presented in this paper were collected during an expedition to the ,tropical alpine" areas of Tarapacá and Antofagasta Regions in Chile that took place in November 2001 by the author. All the specimens cited are deposited in MUB and duplicates, if available, in $\mathrm{CONC}$.

\section{Annotated list of species}

Aloinella andina Delgad.

Tarapacá (Región I): pr. Putre, 18²'05'S, 69³2'34' W, Cano 217; pr. Zapahuira, $18^{\circ} 20^{\prime} 46^{\prime \prime} \mathrm{S}, 6^{\circ} 33^{\prime} 18^{\prime \prime} \mathrm{W}$, Cano 265b. New for Chile.

The new records were on exposed taluss at 3720 $\mathrm{m}$ among shrubs of Compositae and Cactaceae, and on hillside of Polylepis besseri Hieron. and Cactaceae at $3550 \mathrm{~m}$. This species was only previously reported from Peru (Delgadillo 1975; Churchill et al. 2000). The Chilean material shows the typical characters provided by Delgadillo (1975): cucullate-tubulose leaf apex, papillae present on upper dorsal surface of the costa and leaf blade, upper leaf margin membranaceous and costa ending well below tip of hood. However, the lamina cells were less strongly papillose than the type material (holotype-NY!).
Coscinodontella bryanii R.S. Williams

Tarapacá (Región I): pr. Zapahuira, 18²0'46' S, 69³3'18' W, Cano 253; Pukará de Copaquilla, 18²3'02'S, 69³7'52'W, Cano 274. New for Chile.

This interesting species was only known from Matucana in Peru (Williams 1927; Murray 1984) and Bolivia (Churchill et al. 2000). The Chilean specimens were found on rocks on a hillside with Polylepis besseri at $3350 \mathrm{~m}$ and on soils accumulated at the base of rock at $3100 \mathrm{~m}$ in an open puna area. It is mainly characterized by its incurved, cucullate apex, bistratose lamina on the upper part and campanulate plicate calyptra. The Chilean specimen shows a less cucullate apex than the type material (isotype-PC!).

Didymodon acutus (Brid.) K. Saito

Tarapacá (Región I): pr. Zapahuira, 18²0'46' S, 69³3'18'W, Cano 254a. New for Chile.

This first reported sample of this rather wideranging species in Chile was collected on soil acumulated on rocks on a hillside with Polylepis besseri at 3350. According to Churchill et al. (2000), it was known from Venezuela, Colombia and Peru (sub D. rigidulus var. gracilis (Hook. \& Grev.) R.H. Zander) in the tropical Andes. The sample shows the typical characteristic of this species: lanceolate leaves, costa excurrent, with quadrate superficial adaxial cells and smooth lamina cells.

Erythrophyllopsis fuscula (Müll. Hal.) Hilp. Tarapacá (Región I): pr. Zapahuira, 18²0’46"S, 69'33'18' W, Cano 270. New for Chile.

This species was only known from some localities in Bolivia and Argentina (Grandstein et al. 2001). It is close to Erythrophyllastrum andinum (Sull.) R.H. Zander, but can be distinguished by the hyalodermis formed only by one layer of generally collapsed cells, longer lanceolate leaves, usually squarrose when moist, base more strongly sheathing with distinct shoulders and reniform costa transverse section and dorsal estereid band (in E. andinum both are semicircular) (Zander 1993). The new record was collected at $3350 \mathrm{~m}$, in soil acummulated on rock on a hillside with Polylepis besseri and Cactaceae. 
Fissidens excurrentinervis R.S. Williams Antofagasta (región II): Geyseres del Tatio, 22²0'28' S, 6801'08' W, Cano 297. New for Chile.

This new record was found in a crevice of rock in an open puna area at $4260 \mathrm{~m}$. It was easily recognized because it was fertile and showed the typically erect peristome teeth even when moist, irregularly divided and smooth below and spirally striate above. This taxon was known from Bolivia, Mexico and Peru (Pursell 1994).

\section{Grimmia molesta J. Muñoz}

Tarapacá (Región I), pr. Zapahuira, 18²0'46" S, 69'33'18' 'W, Cano 255. New for Chile.

This taxon was described by Muñoz (1999) from a sole sample from Arequipa, Peru (Hegewald \& Hegewald 5480). According to this author, the species is characterized by lanceolate, bistratose leaves with recurved margins, short straight setae, and immersed peristomate capsules with a compound and revoluble annulus. Also, the male buds arise at the ends of branches separated from the perichaetia. The Chilean specimen was found on exposed rock at $3350 \mathrm{~m}$ on a hillside with Polylepis besseri. It presented all the characters provided in the original description with the exception of the leaf margins, which were flat instead of recurved.

Grimmia plagiopodia Hedw.

Tarapacá (Región I): pr. Caquena, 1806'02' S, 69¹6’36'W, Cano 236.

Muñoz (1999) reported this species in South America from Santa Cruz and Mendoza (Argentina) and Magallanes (Chile). He (1998) reported it in XI Region of Chile. This reported, therefore, places it ca. $3500 \mathrm{~km}$ more to the north, near the Bolivian border. The samples presented all the characteristics of this species: unistratose leaves, with curved setae asymmetrically attaching to immersed, ventricose and peristomate capsules. Of note is the absence of hyaline hair-points in all the leaves, even in the perichaetial leaves unlike that recorded by Muñoz (1999) in the description of this species. However, the same author pointed out that South American specimens can present some muticous leaves and well within the expected normal range of variations of G. plagiopodia. The taxon was collected on exposed rock with Azorella sp. in an open puna area at $4500 \mathrm{~m}$.

\section{Grimmia pseudoanodon Deguchi}

Tarapacá (Región I): pr. Caquena, 1806'02'S, 69¹6'36'W, Cano 238a. New for Chile.

Species characterized by ovate to lanceolate leaves with flat margins and short, straight seta, which is centrally attached to the gymnostomous capsule. It was known from Argentina, Bolivia and Peru (Muñoz \& Pando 2000). The new record grew on exposed rock at $4500 \mathrm{~m}$ in open puna areas.

Jaffueliobryum williamsii (Deguchi) Delgad. Tarapacá (Región I): Pukará de Copaquilla, $18^{\circ} 23^{\prime}$ '02' S, 69³7'52' W, Cano 277b. New for Chile.

This taxon was described as an illegitimate name by Williams (1910) from an one specimen from Arequipa, Peru (Grimmia julaceae R.S. Williams). Deguchi (1987) substituted this illegitimate name by Grimmia williamsii Deguchi and suggested its relation with Jaffueliobryum Thér. Muñoz (1999), in his revision of Southern America Grimmia, included this as an excluded taxon and treated the name as a synonym of $J$. wrightii (Sull.) Thér. Finally, Delgadillo (2000) confirmed its inclusion in the genus Jaffueliobryum and provided convincing characters for considering this taxon at species level (J. williamsii (Deguchi) Delgad.). According to this latter author, J. williamsii is mainly characterized by julaceous stems that bear broadly and suborbicular leaves and it can be mainly distinguished from $J$. wrightii by its partly bistratose distal leaf lamina, a costa ranging from percurrent to short-excurrent, plane hair-point and a costal cells without stereids. The new records consists of a few plants with no sporophytes, although the gametophytic characters are more related with J. williamsii and coincide completely with the features provided in Delgadillo (2000). Only, the Chilean specimen presented a longer hair-point in some leaves, reaching up to $0.46 \mathrm{~mm}$ long. Anyway, no Jaffueliobryum has been recorded in Chile. The sample was collected on soil accumulated at the base of rock in an open puna area. 
Leptopteriginandrum austro-alpinum Müll. Hal.

Tarapacá (Región I): pr. Caquena, 1806'02'S, 69¹6'36''W, Cano 235; pr. Parinacota, $18^{\circ} 11^{\prime} 16^{\prime \prime} \mathrm{S}, 69^{\circ} 16^{\prime} 29^{\prime \prime} \mathrm{W}$, Cano 244e; pr.

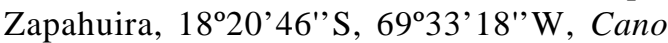
252a. ANTOFAgAsta (REgión II): Geyseres del

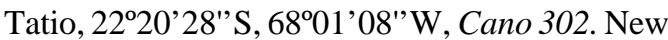
for Chile.

This species is known from Mexico, Alaska, Colorado, Africa and in neotropical areas from Peru to northern Argentina (Gradstein et al. 2001). It also was reported from Asia (Redfearn \& Wu 1986; Ignatov \& Afonina 1992; Tsegmed 2001). The Chilean specimens were collected in fissures of rocks at 3350-4500 $\mathrm{m}$ in an open puna area and on hillside with Polylepis besseri Hieron.

Pseudocrossidium elatum (R.S. Williams) Delgad.

Tarapacá (Región I): pr. Putre, 18²'05'S, 69³2'34' W, Cano 215; pr. Zapahuira, 18²0'46' S, 69³3'18' W, Cano 265a; Pukará de Copaquilla, 18²3'02' S, 69³7' 52' W, Cano 276; carretera Arica-Putre, km 75, 18²6'32''S, 6945'34'W, Cano 280a. New for Chile.

Only reported previosly from Peru and Bolivia (Churchill et al. 2000). The Chilean specimens were found growing with Pseudocrossidium apiculatum R.S. Williams in crevices and fissures of rocks with accumulated soil at 2580$3750 \mathrm{~m}$, among shrubs of Compositae and Cactaceae, in a Browningia candelaris formation and on hillsides with Polylepis besseri and cacti. It is characterized by its smooth laminal cells, with supracostal filaments, lanceolate leaves, whose leaf margins are not differentiated as photosynthetic organs, and with some stereid cells sometimes differentiated immediately below the ventral filaments. It also has weakly differentiated perichaetial leaves, and axillary hairs with the basal cells thickened and brownish similar to those found in the genus Didymodon. In other Pseudocrossidium and Crossidium studied the basal cell of the axillary hairs was hyaline and thin walled. According to Zander (1993), this species shows an uncomfortably intermediate morphology between
Pseudocrossidium and Crossidium; he also suggests the recognition of this species as a monotypic genus.

\section{Rhexophyllum subnigrum (Mitt.) Hilp.}

Tarapacá (Región I): pr. Chañopalca, $18^{\circ} 01^{\prime} 35^{\prime \prime} \mathrm{S}, 69^{\circ} 18^{\prime} 17^{\prime \prime} \mathrm{W}$, Cano 242a; pr. Zapahuira, 18 $20^{\circ} 46^{\prime \prime} \mathrm{S}, 6^{\circ} 33^{\prime} 18^{\prime \prime} \mathrm{W}$, Cano

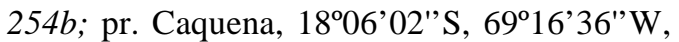
Cano 231. New for Chile.

Known from Argentina, Bolivia, Mexico, Peru, Southwestern United States (Gradstein et al. 2001) and Guatemala and Honduras (Allen 2002). The Chilean collections were found in fissures and soil accumulated on bases of rocks, at 3350-4560 m on hillsides of Polylepis besseri, rocky areas with Polylepis tarapacana and Azorella and in an open puna area. According to Zander (1993), this species is easily recognized by its lanceolate leaves which are widely spreading to squarrose when moist, with upper margins sharply and deeply dentate and laminal cells bistratose in patches across the leaves with the epidermis costa absent or weakly differentiated ventrally.

Saitobryum lorentzii (Müll. Hal.) Ochyra Tarapacá (Región I): pr. Zapahuira, 18²0'46" S, 69'33'18' 'W, Cano 251c; carretera Arica-Putre, km 75, 18²6'32''S, 6945'34''W, Cano 278, 280c. New for Chile.

The specimens were found on soil accumulated on rocks among vegetation dominated by cacti and Polylepis besseri at $3350 \mathrm{~m}$ and in a Browningia candelaris formation at $2580 \mathrm{~m}$. It was known from Argentina (Müller 1882; Ochyra 1999) and Ecuador, Mexico and Peru (Gradstein et al. 2001). This species is distinguished by its obovate leaves, the absence of guide cells, the presence of a single stereid band on the dorsal side of the leaf and a wide band of smooth laminal cells along the margins of the upper half of the leaf, giving way to pluripapillose cells in the medial zone of the upper lamina cells (Zander 1993).

Syntrichia fragilis (Taylor) Ochyra

Tarapacá (Región I): pr. Putre, 18²1205'S, 69³2'34'’ W, Cano 213; pr. Zapahuira, 
18²0'46'S, 69³3'18' W, Cano 258. New for Chile.

This species is easily characterized by its oblonglingulate to spathulate, muticous leaves, costa with hydroids and 3-5 stereid layers and, above all, by its fragile leaves which tend to detach in to fragments in any part of the lamina. It was collected in fissures and exposed rocks at 2550$3720 \mathrm{~m}$ among shrubs of Compositae and Cactaceae, and on hillside of Polylepis besseri and cacti. It is a wide-ranging species known from North-Central, Southwestern, SouthCentral, and Southeastern U.S.A.; Mexico; Central America, Caribbean, Western, Northern, and Southern South America, Brazil; Southwestern, Middle, and Southeastern Europe; Western Asia, Arabian Peninsula, China; Macaronesia, Northern Africa Northeast, WestCentral, East, and South Tropical Africa, Southern Africa; Indian subcontinent (Allen 2002). In tropical Andes it has been recorded in Bolivia, Colombia, Ecuador, Peru and Venezuela (Churchill et al. 2000).

\section{Acknowledgements}

I am very grateful to J.J. Jiménez (Didymodon acutus), J. Muñoz (Grimmiaceae), R. Pursell (Fissidens excurentinervis) and M.T. Gallego (Syntrichia fragilis) for the confirmation of those taxa. I thank B. Thiers (NY) for the loan of specimens and J. Guerra for his review of a first version of the manuscript. Also, I am very grateful to the Departamento de Botánica, Universidad de Concepción for their assistance during my stay in Chile. Funding for Paris (PC) was provided by Colparsyst program of the European Community and the Chilean trip by the Spanish Ministry of Education, Culture and Sports (PR2001-0293).

\section{References}

Allen, B. 2002. Moss Flora of Central America. Part 2. Encalyptaceae-Orthotrichaceae. Monographs in Systematic Botany from the Missouri Botanical Garden 90: 1-699.

Churchill, S. P., D. Griffin III \& J. Muñoz. 2000. A checklist of the mosses of the tropical Andean countries. Ruizia 17: 1-303.

Deguchi, H. 1987. Studies on some Peruvian species of the Grimmiaceae (Musci, Bryophyta), pp. 19-74. In H. Inoue (ed.), Studies on cryptogams in southern Peru. Tokai University Press, Tokyo.

Delgadillo, M. C. 1975. Taxonomic revisión of Aloina, Aloinella and Crossidium (Musci). Bryologist 78: 245-303.

Delgadillo, M. C. 2000. Taxonomy of Grimmia williamsii. Journal of Bryology 22: 294297.

Gradstein, S. R., S. P. Churchill \& N. SalazarAllen. 2001. Guide to the bryophytes of Tropical America. Memoirs of the New York Botanical Garden 86: 1-577.

Grau, J. 1995. Aspectos geográficos de la flora de Chile, pp. 63-83. In C. Marticorena, \& R. Rodríguez (eds.), Flora de Chile. Vol. 1. Pteridophyta-Gimnospermae. Anibal Pinto S.A., Concepción.

He, S. 1998. A checklist of the mosses of Chile. Journal of the Hattori Botanical Laboratory 85: 103-189.

Ignatov, M. S. \& O. M. Afonina. 1992. Checklist of mosses of the former USSR. Arctoa 1: $1-85$.

Müller, C. 1882. Prodromus bryologiae argentinicae. I. Linnaea 42: 217-486.

Muñoz, J. 1999. A revision of Grimmia (Musci, Grimmiaceae) in the Americas. 1: Latin Americas. Annals of the Missouri Botanical Garden 86: 118-191.

Muñoz, J. \& F. Pando. 2000. A world synopsis of the genus Grimmia (Musci, Grimmiaceae). Monographs in Systematic Botany from the Missouri Botanical Garden 83: 1-133.

Murray, B. 1984. A revision of the monotypic genera Indusiella, Aligrimmia and Coscinodontella (Musci: Grimmiaceae), with comments on convergent xeromorphological features. The Bryologist 87: 24-36.

Ochyra, R. 1999. New combinations in neotropical mosses. Fragmenta Floristica et Geobotanica 44: 255-259.

Pursell, R. 1994. Fissidentales. In A. J. Sharp, H. Crum \& P. M. Eckel (eds.), The Moss Flora of Mexico. Part 1. Sphagnales to Bryales. Memoirs of the New York Botanical Garden 69: 31-81.

Redfearn, P. L., J.r. \& P.-C. Wu. 1986. Catalog of the mosses of China. Annals of the Missouri Botanical Garden 73: 177- 208.

Tsegmed, TS. 2001. Checklist and distribution of mosses in Mongolia. Arctoa 10: 1-18.

Williams, R.H. 1910. Bolivian Mosses. Part II. Bulletin of the New York Botanical Garden 6: 227-261. 
Williams, R.H. 1927. Mosses of Peru collected by the Captain Marshall Field Peruvian Expedition 1923. Publications of the Field Museum of Natural History. Botanical Series 4: 125-139.

Zander, R. H. 1993. Genera of the Pottiaceae: Mosses of harsh environments. Bulletin of the Buffalo Society of Natural Sciences 32: 1-378. 